\title{
The Effect of Urea Levels on In-vitro Digestibility and Rumen Fermentation Characteristic of Ammoniated Oil Palm Trunk
}

\author{
Azhary Noersidiq ${ }^{\mathrm{a}}$, Yetti Marlida ${ }^{\mathrm{a}, 1}$, Mardiati Zain ${ }^{\mathrm{a}}$, Anwar Kasim ${ }^{\mathrm{b}}$, Fauzia Agustin ${ }^{\mathrm{b}}$, Nurul Huda ${ }^{\mathrm{c}, \mathrm{d}}$ \\ ${ }^{a}$ Department of Animal Nutrition and Feed Technology, Faculty of Animal Science, University of Andalas, Padang 25163, Indonesia \\ Email: I'yettimarlida@ansci.unand.ac.id \\ ${ }^{b}$ Department of Agricultural Technology, Faculty of Agricultural Technology, University of Andalas, Padang 25163, Indonesia \\ ${ }^{c}$ Faculty of Food Science and Nutrition, Universiti Malaysia Sabah, 88400, Kota Kinabalu, Sabah, Malaysia \\ Email: drnurulhuda@ums.edu.my \\ ${ }^{d}$ Faculty of Agriculture, University of Sultan Ageng Tirtayasa, Banten 42124, Indonesia
}

\begin{abstract}
The purpose of this research to evaluate the effect of urea levels for ammoniated of oil palm trunk on in vitro digestibility and rumen fermentation characteristics. The treatment was A0 = Oil palm trunk without treated (control), A1: ammoniated oil palm trunk using 2\% urea; A2: ammoniated oil palm trunk using 4\% urea; A3: ammoniated oil palm trunk using 6\% urea; A4: ammoniated oil palm trunk using 8\% urea; A5: ammoniated oil palm trunk using $10 \%$ urea. The variables measured were in vitro digestibility such as dry matter, organic matter, crude protein and fiber fractions (NDF, ADF, cellulose and hemicellulose), concentration of $\mathrm{NH}_{3}$ and total of volatile fatty acid (VFA) and pH value. Data was analyzed using SAS program with analysis of variance test (ANOVA) and Duncan's multiple range test (DMRT). The results obtained showed that the using of urea with various levels of oil palm trunk ammoniation was significant $(P<0.01)$ increased in vitro digestibility of dry matter (IVDM), organic matter (IVOM), crude protein (IVCP) and fiber fraction digestibility, $\mathrm{pH}$ value, $\mathrm{NH}_{3}$ and total of VFA concentration compared to control (A0). It can be concluded that the using of level $6 \%$ urea gave the best result for ammoniation of oil palm trunk such as IVDM: 45.91\%, IVOM: $46.33 \%$, IVCP: $61.51 \%$ and in vitro digestibility of NDF: 43.34\%, ADF: 38.20\%, cellulose: $44.28 \%$, hemicellulose: 63.25\% whereas pH: 7.02, $\mathrm{NH}_{3}: 9.02 \mathrm{mg} / 100 \mathrm{ml}$ and total VFA: $99.57 \mathrm{mM}$ respectively.
\end{abstract}

Keywords - ammoniated oil palm trunk; digestibility; rumen characteristic; in vitro.

\section{INTRODUCTION}

The potential of oil palm growth in Indonesia is very high with a plantation area of 12.4 million $\mathrm{Ha}$ in 2017 and it is expected to increase every year. The largest distribution of plantation in Indonesia such as Riau, North Sumatra, Central Kalimantan, South Sumatra and West Kalimantan provinces [1]. As the area under oil palm plantations continues to increase in Indonesia over years, replantation of oil palm plantations will increase too. The consequences of this replanting will lead to the production of oil palm wastes too much especially oil palm trunk that can be used as animal feed.

Oil palm replantation is an activity to replace the old oil palm plants that are no longer economical compared to new oil palm plants or 25-30 years old of being planted. The oil palm trunk from replantation that can be used as animal feed is the pith or the inside of the trunk which has been separated from the outer layer. Guritno and Darnoko [2] stated that the average area of replantation during the period of $2001-2005$ was $32,155 \mathrm{ha} /$ year. Oil palm trunk was generated at 2.26 million tons per year, while in the period of 2006 - 2010 there was an increase in the area of replanting oil palm plantations, which averaged 89,965 hectares annually. During this period of replanting oil palm plantations solid waste production reached 6.3 million tons per year.

In terms of the quantity of oil palm waste which reaches 6.3 million tons per year, it has potential to become beef cattle feed, where the part that can be utilized is the pith from the stem of the oil palm. The percentage of pith in the stem of oil palm reaches $75 \%$ of the total stem so that from the total palm oil waste per year reaching 6.3 million tons, it can be used as animal feed at 4.72 million tons of oil palm pith. While in terms of quality, oil palm trunk contains high crude fiber ranging from $44 \%$ where crude fiber is the main energy source for ruminants. Oil palm trunk as ruminant feed have limitations because the high lignin content in them. 
Therefore, to further increase digestibility and nutritional value of oil palm trunk cellulars, first processing is done with ammonia technology.

Ammoniation is one method of processing feed chemically by adding alkalis and acids which are fermented aerobically or anaerobically [3]. The three sources of ammonia that can be used in the ammoniation process are $\mathrm{NH}_{3}$ in the form of liquid gas, $\mathrm{NH}_{4} \mathrm{OH}$ in the form of solution, and urea or $\left(\mathrm{NH}_{2}\right)_{2} \mathrm{CO}$ in solid form. The recommended source of ammonia for use is urea because it is cheaper, easier to use, and less toxic. Urea can loosen lignosellulosa and lignohemisellulosa bonds so that lignosellulose swells and the cellulose part of the crystal decreases and consequently facilitates the penetration of enzymes produced by rumen microbes [4]. Ammoniation also increases the nitrogen content through fixation of nitrogen into the tissues of feed ingredients which are then counted as protein ingredients and function as preservatives in feed ingredients.

Ammoniation technology has been usually applied in the processing of ruminant feed and has been shown the positive effect on digestibility, consumption and performance of cattle. Several studies on the application of ammonia technology for ruminant feed ingredients include rice straw ammonia [5, 6, 7], bagasse ammonia [8], oil palm leaf waste ammonia [4] and oil palm frond ammonia [9, 10]. Whereas for oil palm trunk waste itself has been used as ruminant animal feed by processing fermentation with commercial microbial Starbio and white rot fungus (Phanerochaete chrysosporium) [11, 12]. However, the application with ammoniation technology has never been applied to oil palm trunk where ammonization technology is easier to implement, relatively inexpensive, easy to handle, non-toxic and has a high nitrogen content. The purpose of this research was to evaluate the using effect of urea levels for ammoniated of oil palm trunk on in vitro digestibility and fermentation characteristics in the rumen.

\section{MATERIAL AND METHOD}

\section{A. Experimental Design}

The material used was oil palm trunk taken from oil palm plantations of Andalas University. The oil palm trunk is processed into smaller sizes by shredding machine and then treated with ammoniation technology using urea with various level from $0 \%$ until $10 \%$. The urea used is obtained from the poultry shop in the city of Padang. The rumen liquid used came from the slaughterhouse of the city of Padang, a chemical for McDougal buffer and for proximate, van soest, $\mathrm{NH}_{3}$ and VFA analysis. The nutritional content of oil palm trunk for fresh and ammoniation can be seen in (Table 1). It used a randomized block design (RBD) with six treatments and three replications of rumen fluid taken. The treatments were A0: oil palm trunk without treatment (control); A1: ammoniated oil palm trunk using 2\% urea; A2: ammoniated oil palm trunk using $4 \%$ urea; A3: ammoniated oil palm trunk using 6\% urea; A4: ammoniated oil palm trunk using $8 \%$ urea; A5: ammoniated oil palm trunk using $10 \%$ urea.

TABLE I

THE NUTRITIONAL CONTENT OF OIL PALM TRUNK (OPT) FOR FRESH AND AMMONIATION

\begin{tabular}{|l|r|r|r|r|r|r|}
\hline \multirow{2}{*}{ Parameters (\%) } & \multicolumn{7}{|c|}{ Level of urea (\% in DM) } \\
\cline { 2 - 7 } & $\mathbf{A 0}$ & $\mathbf{A 1}$ & $\mathbf{A 2}$ & $\mathbf{A 3}$ & $\mathbf{A 4}$ & A5 \\
\hline Dry Matter & 44.00 & 43.20 & 41.06 & 40.64 & 40.08 & 39.95 \\
\hline Organic Matter & 95.07 & 94.87 & 94.32 & 93.71 & 92.45 & 92.08 \\
\hline Crude Protein & 3.22 & 4.40 & 6.56 & 8.60 & 10.52 & 12.76 \\
\hline Crude Fat & 3.34 & 3.09 & 2.89 & 2.49 & 2.03 & 1.96 \\
\hline Crude Fiber & 44.91 & 44.36 & 43.78 & 43.53 & 42.32 & 41.62 \\
\hline ADF & 62.12 & 62.30 & 62.68 & 63.25 & 64.36 & 65.19 \\
\hline NDF & 81.64 & 80.75 & 80.54 & 79.55 & 79.33 & 76.47 \\
\hline Cellulose & 46.22 & 46.83 & 49.70 & 51.17 & 53.17 & 54.93 \\
\hline Hemicellulose & 19.52 & 18.45 & 17.86 & 16.30 & 14.97 & 11.28 \\
\hline Lignin & 15.03 & 14.69 & 12.24 & 11.50 & 10.72 & 10.01 \\
\hline
\end{tabular}

Source: (Data unpublished)

Note: $A O=O P T$ without treatment, $A 1=A O+2 \%$ urea, $A 2=A O+4 \%$ urea, $A 3=A O+6 \%$ urea, A4: AO+ $8 \%$ urea and $A 5=A O+$ $10 \%$ urea.

\section{B. Ammoniation of oil Palm Trunk Process}

Oil palm trunk collected in pith form and it used as substrate. It was be cut off $1 \mathrm{~m}$ from the base of the stem to 7 $\mathrm{m}$ of height. After that, the palm oil trunk was peeled from the outer skin $10 \mathrm{~cm}$ from the outer skin surface so that the palm oil pith is obtained. It was shredded and sieved to 18 20 mesh by shredding machine and is ready to be amoniated using urea. Ammoniation was carried out by weighing 100 grams of oil palm pith which was then mixed with urea according to the treatment dose and after that it added the water until they reached $60 \%$ of dry matter content. Furthermore, it was incubated into a glass bottle for 21 days in an anaerobic condition. After 21 days, the ammoniated oil palm trunk was dried at $60{ }^{\circ} \mathrm{C}$ in an oven for $12 \mathrm{~h}$ and then analyzed proximate [13] and van soest [14] analysis.

\section{In vitro Digestibility Examination}

In vitro digestibility examination was according to Tilley and Terry method's [15]. The cow rumen fluid was diluted using McDougal buffer with ratio (1: 4) as much as $250 \mathrm{ml}$ 
and mixed with 1-gram sample (ammoniated oil palm trunk) into erlenmeyer. After that it flowed with $\mathrm{CO}_{2}$ gas to maintained an aerobic condition and it incubated in a shaker water bath at $39^{\circ} \mathrm{C}$ for 48 hours. After 48 hours, the erlenmeyer was inserted into ice water to stop the fermentation process and then it centrifuged at $1.200 \mathrm{rpm}$ for 15 min to separate between supernatant and sample. The supernatant used to analyze of $\mathrm{pH}, \mathrm{NH}_{3}$ and total of volatile fatty acid (VFA). The $\mathrm{NH}_{3}$ concentration was analyzed using the micro-diffusion Conway method's [16] and the total of VFA concentration was analyzed using the steam distillation method's [17]. The sample was filtered with Whatman no. 41 and dried at $60^{\circ} \mathrm{C}$ in an oven for 2 days. It used to analyze digestibility of nutrient content such as dry matter, organic matter, crude protein, NDF, ADF, cellulose and hemicellulose.

\section{Statistical Analysis}

Variance analysis was performed to find out the effect of treatment on the observed parameters. If there are differences, a test will be conducted with Duncan's multiple range test (DMRT) using SAS program [18].

\section{RESULT AND DISCUSSION}

\section{A. The effect of Ammoniation on In-vitro Digestibility of Nutrient Contents}

Based on analysis of variance showed that the treatments had a highly significant effect $(P<0.01)$ on digestibility of dry matter, organic matter, crude protein and fiber fraction. It can be seen in Table 2 .

TABLE II

DIGESTIBILITY OF DRY MATTER, ORGANIC MATTER, CRUDE PROTEIN, ADF, NDF, CELLULOSE AND HEMICELLULOSE

\begin{tabular}{|l|c|c|c|c|c|c|}
\hline \multirow{2}{*}{ Parameters (\%) } & \multicolumn{5}{|c|}{ Level of urea (\% in DM) } \\
\cline { 2 - 7 } & $\mathbf{A 0}$ & $\mathbf{A 1}$ & $\mathbf{A 2}$ & $\mathbf{A 3}$ & $\mathbf{A 4}$ & $\mathbf{A 5}$ \\
\hline Dry matter & $41.43^{\mathrm{D}}$ & $42.34^{\mathrm{D}}$ & $42.65^{\mathrm{CD}}$ & $45.91^{\mathrm{A}}$ & $44.13^{\mathrm{B}}$ & $43.85^{\mathrm{BC}}$ \\
\hline Organic matter & $41.54^{\mathrm{D}}$ & $42.61^{\mathrm{C}}$ & $43.86^{\mathrm{B}}$ & $46.33^{\mathrm{A}}$ & $45.44^{\mathrm{A}}$ & $45.26^{\mathrm{A}}$ \\
\hline Crude protein & $54.19^{\mathrm{C}}$ & $54.48^{\mathrm{C}}$ & $57.56^{\mathrm{B}}$ & $61.52^{\mathrm{A}}$ & $58.98^{\mathrm{B}}$ & $58.91^{\mathrm{B}}$ \\
\hline NDF & $39.83^{\mathrm{E}}$ & $40.38^{\mathrm{DE}}$ & $41.39^{\mathrm{C}}$ & $43.34^{\mathrm{A}}$ & $42.23^{\mathrm{B}}$ & $40.83^{\mathrm{CD}}$ \\
\hline ADF & $33.31^{\mathrm{E}}$ & $34.22^{\mathrm{D}}$ & $35.72^{\mathrm{C}}$ & $38.20^{\mathrm{A}}$ & $37.55^{\mathrm{AB}}$ & $37.13^{\mathrm{B}}$ \\
\hline Cellulose & $40.45^{\mathrm{C}}$ & $41.32^{\mathrm{BC}}$ & $41.84^{\mathrm{BC}}$ & $44.28^{\mathrm{A}}$ & $43.21^{\mathrm{AB}}$ & $42.93^{\mathrm{AB}}$ \\
\hline Hemicellulose & $60.55^{\mathrm{D}}$ & $61.18^{\mathrm{C}}$ & $61.32^{\mathrm{C}}$ & $63.25^{\mathrm{A}}$ & $62.34^{\mathrm{B}}$ & $62.22^{\mathrm{B}}$ \\
\hline
\end{tabular}

This is because the influence of urea in the ammoniation of oil palm trunk stretches the bond between lignin and the fiber fraction making it easier to digest by the rumen microbes as indicated by the increasing digestibility. The presence of cellulose, hemicellulose in plant cell walls generally binds to lignin. The function of lignin is to help erect the plants but at high concentrations it will protect plant cell wall material from rumen microbial degradation [19]. Cellulose and hemicellulose can be digested as potential energy for ruminants, while lignin cannot be digested by rumen microbes [20].

Lignin reduction cause by the effect of urea treatment can be seen in (Table 1) which show a decrease in the lignin content of oil palm trunk which is $15.03 \%$ to up to $10.01 \%$ based on urea level from $0-10 \%$. This is according with the opinion of Isroi [21] which stated that the ammonia treatment using ammonia source material in the form of urea has been shown to increase the digestibility of feed organic matter. This is because the treatment of urea is the result of two processes carried out simultaneously, namely urea hydrolysis (ureolysis) and the work of ammonia on the cell wall of the material. Hydrolysis of urea is an enzymatic reaction that requires the enzyme urease in the treatment medium. Urea which has decomposed into $\mathrm{NH}_{3}$ will bind with water or $\mathrm{H}_{2} \mathrm{O}$ and undergo hydrolysis to $\mathrm{NH}^{4+}$ and $\mathrm{OH}$. $\mathrm{NH}_{3}$ which is in a neutral atmosphere or $\mathrm{pH} 7$ will be more present as $\mathrm{NH}^{+}$so that ammoniation will be similar to alkaline treatment. The $\mathrm{OH}$ group can break the hydrogen bonds between carbons in glucose molecules found in cellulose, lignocellulose, and lignohemelulose bonds. The two bonds are alkaline labile (can be cut off by alkali treatment) so that the feed will be easier to expand and digest by rumen microbes. According to Hanafi [22] stated that expansion of feed will dissolve lignin deposits in the walls and spaces between cells so that the ammoniation treatment can also reduce food phosphate levels that are difficult and not even digested by livestock and have an impact on increasing feed digestibility.

Nutritional digestibility of all parameters showed an increase both from treatment $\mathrm{A} 0$ to $\mathrm{A} 3$. However, in treatment A4 and A5 it has decreased. The results of further tests using Duncan's test showed that dry matter digestibility, organic matter and crude protein and fiber fraction in treatment A3 (ammoniation with 6\% urea) gave the highest value namely IVDM: $45.91 \%$, IVOM: $46.33 \%$, IVCP: $61.51 \%$ and in vitro digestibility of NDF: $43.34 \%$, ADF: $38.20 \%$, cellulose: $44.28 \%$, hemicellulose: $63.25 \%$ and then followed by other treatments namely A4, A5, A2, A1, and A0. This is due to the use of urea has been maximized at the level of $6 \%$ and for levels $8 \%$ and $10 \%$ has decreased rumen microbial activity in digesting feed ingredients caused by $\mathrm{pH}$ conditions or acid base balance in the rumen which has increased thereby reducing digestibility.

This is consistent with the opinion of Crampton and Harris [23] which stated that food digestibility depends on rumen microbial activity because rumen microbes play a role in the fermentation process, while microbial activity itself is influenced by food substances contained in feed ingredients. The $\mathrm{pH}$ value is one of important factors that controlled the activity of microorganisms in the anaerobic process which is 
the normal $\mathrm{pH}$ between 6.0 to 7.0 [24]. According to Gallert and Winter [25], changes in environmental conditions will affect the growth and early life of bacteria, so bacteria that are unable to adapt to these conditions will experience death due to environmental conditions that do not support the bacterial metabolic process

Along with the increased use of urea, the availability of food substances such as crude protein has increased from $3.22 \%$ to $12.76 \%$. This increasing in crude protein comes from urea which is a source of NPN (non-protein nitrogen) for the formation of rumen microbial proteins and fiber fractions which are the main energy sources for rumen microbes. Where NPN in the rumen will be used for microbial protein synthesis, while proteins will be degraded by proteolytic enzymes produced by rumen microbes into peptides and amino acids [26].

\section{B. The effect of Ammoniation on Rumen Fermentation Characteristic}

Based on analysis of variance showed that the treatment had a highly significant effect $(P<0.01)$ on rumen fermentation characteristics such as $\mathrm{pH}, \mathrm{NH}_{3}$ and VFA concentrations. It can be seen in Table 3 .

TABLE III

THE VALUE OF $\mathrm{PH}, \mathrm{NH}_{3}$, AND TOTAL VFA

\begin{tabular}{|l|c|c|c|c|c|c|}
\hline \multirow{2}{*}{ Parameters (\%) } & \multicolumn{6}{|c|}{ Level of urea (\% in DM) } \\
\cline { 2 - 7 } & A0 & A1 & A2 & A3 & A4 & A5 \\
\hline $\mathrm{pH}$ & $6.96^{\mathrm{C}}$ & $7.00^{\mathrm{B}}$ & $7.01^{\mathrm{B}}$ & $7.02^{\mathrm{B}}$ & $7.04^{\mathrm{A}}$ & $7.05^{\mathrm{A}}$ \\
\hline $\mathrm{NH}_{3}(\mathrm{mM})$ & $6.11^{\mathrm{D}}$ & $7.63^{\mathrm{CD}}$ & $8.33^{\mathrm{C}}$ & $9.02^{\mathrm{B}}$ & $9.61^{\mathrm{A}}$ & $10.00^{\mathrm{A}}$ \\
\hline $\mathrm{VFA}(\mathrm{mM})$ & $85.25^{\mathrm{D}}$ & $86.25^{\mathrm{D}}$ & $91.91^{\mathrm{C}}$ & $99.57^{\mathrm{A}}$ & $97.23^{\mathrm{B}}$ & $96.90^{\mathrm{B}}$ \\
\hline
\end{tabular}

${ }^{A B C}$ Means in the same row with common letter are very different $(P<0.01)$

This is caused by the use of urea with various levels during the ammoniation process increasing the $\mathrm{pH}$ conditions in the rumen so that it increases $\mathrm{pH}$, the total gas concentration of $\mathrm{NH}_{3}$ and VFA. The results of further tests using Duncan's test showed that $\mathrm{pH}, \mathrm{NH}_{3}$ in treatment $\mathrm{A} 3$ were significantly different $(P<0.01)$ with other treatments and between treatments were also different. This is because the treatment of urea increase the content of acrude protein from $3.22 \%$ until $12.76 \%$ (Table 1) where it is a source of NPN (non- protein nitrogen) is quickly digested directly in the rumen into ammonia, thus affecting the condition of the rumen $\mathrm{pH}$ to be higher and the $\mathrm{NH}_{3}$ produced also increases with increasing levels of urea given. This is consistent with the statement that urea feed consumed by livestock enters the rumen, dissolves quickly and is hydrolyzed to ammonia by bacteria in the rumen [27]. The degradation of proteins in the rumen produces ammonia, Volatile Fatty Acid (VFA) and $\mathrm{CO}_{2}$. However, the total VFA produced tends to increase with increasing levels of urea use but there is a decrease in treatment A4 and A5. This is because the urea that is too high will affect the condition of the rumen $\mathrm{pH}$ too high which affects the work of microbes in digesting and producing gases such as VFA and $\mathrm{NH}_{3}$.

The average $\mathrm{pH}$ value produced in this study ranges from $6.96-7.05$ and this is higher than the normal $\mathrm{pH}$ of the rumen. while the $\mathrm{pH}$ range is ideal for microbial activities which are between 6.0 and 7.0 [24]. This is because the addition of urea increases the $\mathrm{pH}$ in the rumen so that the $\mathrm{pH}$ becomes higher. The process of microbial growth and metabolism is not disturbed in normal rumen $\mathrm{pH}$ conditions, so that microbial activity runs normally and the digestion process for feed ingredients will be optimal.

The average concentration of $\mathrm{NH} 3$ produced in this research was A0 $(6.11 \mathrm{mg} / 100 \mathrm{ml})$, A1 $(7.63 \mathrm{mg} / 100 \mathrm{ml})$, A2 $(8.33 \mathrm{mg} / 100 \mathrm{ml})$, A3 $(9.02 \mathrm{mg} / 100 \mathrm{ml})$, A4 $(9.61$ $\mathrm{mg} / 100 \mathrm{ml})$ and $\mathrm{A} 5(10.00 \mathrm{mg} / 100 \mathrm{ml})$. These results are still within the normal range. Purbowati et al., [28] stated that NH3 concentrations required for the maximum rate of microbial protein synthesis range between $3-8 \mathrm{mg} / 100 \mathrm{ml}$ and according to McDonald et al., [29], the range of NH3 optmum in the rumen range between $85-300 \mathrm{mg} / \mathrm{l}$ or $6-21$ $\mathrm{mM}$. The increase in the percentage of NH3 value is cause by the oil palm trunk ammoniation containing a high amount of NPN and directly being easily degraded into energy to form NH3. Orskov [30] stated that in ruminants, some of the protein entering the rumen will undergo degradation to ammonia by proteolytic enzymes produced by rumen microbes. Ammonia production depend on the solubility of the protein ration, the amount of protein ration, the length of food in the rumen and rumen $\mathrm{pH}$. The high level of $\mathrm{NH} 3$ produced in treatment A5 is caused by the high level of urea used in the ammonia of oil palm trunk so that the resulting NPN is high and causes high production of ammonia (NH3) but not significantly different $(\mathrm{P}>0.05)$ with $\mathrm{A} 3$ and $\mathrm{A} 4$.

The average VFA concentration produced in the research was A0 (85.25 mM), A1 (86.25 mM), A2 (91.91 mM), A3 (99.57 mM), A4 (97.23 mM) and A5 (96.90 mM). The results are far higher than Astuti [31] which researched of the characteristics of oil palm waste from fermentation with local microorganisms of livestock waste as ruminant feed ingredients resulting in a VFA concentration of 54.46 $72.26 \mathrm{mM}$. While the VFA value needed to support optimal rumen, microbial growth is $70-150 \mathrm{mM}$ [29]. This increasing caused by the high content of crude fiber and the NPN source of urea in the oil palm trunk ammoniation which is easily degraded by microbes in the rumen resulting in higher energy. In addition, VFA levels are determined by crude fiber digestibility where the higher the digestibility, the higher the level of VFA produced. In this research, A3 treatment using the level of $6 \%$ urea for ammoniation of oil palm trunk gave the highest digestion of fiber fraction (Table 2) so as to produce high VFA levels as well which was equal to $99.57 \mathrm{mM}$. This is supported by the statement by Liu et al., [32] stated that there is a strong correlation between the 
digestibility of organic matter and dry matter in total VFA production and the highly in vitro digestibility of organic matter and crude fiber will increase the total production of rumen VFA.

\section{IV.CONCLUSION}

Ammoniation of oil palm trunk using 6\% urea was gave the best result with IVDM: $45.91 \%$, IVOM: 46.33\%, IVCP: $61.52 \%$ and in vitro digestibility of NDF: $43.34 \%$, ADF: $38.20 \%$, cellulose: $44.28 \%$, hemicellulose: $63.25 \%$ whereas rumen fermentation characteristics such as $\mathrm{pH}: 7.02, \mathrm{NH}_{3}$ : $9.02 \mathrm{mg} / 100 \mathrm{ml}$ and total of VFA: $99.57 \mathrm{mM}$ respectively.

\section{ACKNOWLEDGMENT}

This research was funded by the Ministry of Research, Technology and Higher Education of The Republic of Indonesia (RisTekDikti) No: 1387/E4. /2015. We are very grateful to their support.

\section{REFERENCES}

[1] Directorate General of Plantations. 2016. Statistics of Indonesian palm oil. Ministry of Agriculture. Jakarta. Indonesia (In Indonesian)

[2] Guritno P and Darnoko. 2003. Technology for utilizing waste from oil palm replantation. National Seminar: Anticipating the First Regeneration of Oil Palm Plantations in Indonesia, 9 - 10 April 2003. Bali: Max Havelaar Indonesia Foundation. Indonesia (In Indonesian)

[3] Pigden WJ and Bender F. 1978. Utilization of lignosellulosa by ruminant. In ruminant nutrition. Selected articles from the world animal review. FAO. United Nation, Rome. pp 30-33.

[4] Hanafi ND. 2004. The silage and ammoniation treatment of palm oil leaves as raw material for sheep feed. Faculty of Agriculture. Digital library. University of North Sumatera. Medan. Indonesia (In Indonesian)

[5] Wahyuni and Bijanti R. 2006. Test of side effect of complete feed formula on renal and liver function of Friesian Holstein calf. Media Kedokteran Hewan. 22(3): 174-178. Indonesia (In Indonesian)

[6] Davies ZS, Mason, Brooks AE, Griffith GW, Merry and Theodora MK. 2000. An automated system for measuring gas production from forages innoculated with rumen fluid and its use in determining the effect of enzymes on grass silage. Animal Feed Science and Technology. 83(3-4): 205-221

[7] Sumarsih S and Tampoebolon BIM. 2003. Effect of urea ammonation of Eichornia crassipess on its physical properties. Journal of the Indonesian Tropical Animal Agriculture. Special Edition October: 298-301. Indonesia (In Indonesian)

[8] Permata AT. 2012. Effect of ammonia with urea on sugarcane bagasse on the content of dry matter, crude fiber and crude protein for animal feed supply. Unpublished scientific articles. Faculty of Veterinary Medicine. Airlangga University. Surabaya. Indonesia (In Indonesian)

[9] Zain M, Sutardi T, Suryahadi and Ramli N. 2008. Effect of defaunation and supplementation methionine hydroxyl analogue and branched chain amino acid in growing sheep diet based on palm press fiber ammoniated. Pakistan Journal of Nutrition, 7(6): 813-816

[10] Suryani H, Zain M, Rusmana WSN and Novesar J. 2016. Supplementation of direct fed microbial (DFM) on in vitro fermentability and degradability of ammoniated palm frond. Pakistan Journal of Nutrition. 15(1): 89-94
[11] Marlida Y, Arnim and Arief S. 2016. Profil fiber digestibility in vitro of oil palm trunk fermented by Phanerochaete chrysosporium. MP3EI Reports. Andalas University. Indonesia

[12] Azhary N, Yetti M, Mardiati Z, Anwar K and Fauzia A. 2018. The effect of bioprocess technology in oil palm trunk on chemical composition and in-vitro fermentation characteristics. Asian Journal of Microbiology, Biotechnology \& Environmental Sciences, 20: 2018: S102-S108.

[13] AOAC. 1995. Official methods of analysis of the association of official analytical chemists. Washington: AOAC

[14] Van Soest PJ. 1982. Nutrional ecology of the ruminant: ruminant metabolism, nutrional strategies the cellulolytic fermentation and the chemistry of forages and plant fibers. Cornell University O and B Books Inc. USA

[15] Tilley JMA and Terry RA. 1963. A two-stage technique for in vitro digestion of forage crop. The Journal of the British Grassland Society, 18: 104-111.

[16] Conway EJ and E O'Malley. 1942. Microdiffusion methods: ammonia and urea using buffered absorbents (revised methods for ranges greater than $10 \mu \mathrm{g} \mathrm{N}$ ). Biochemistry Journal, 36: 655-66.

[17] General laboratory prosedure. 1996. Departement of dairy science, University of Wisconsin. USA

[18] SAS institute Inc. 2008. SAS User's Guide, Version 9.1, second ed. SAS Institute Inc. Cary, NC.

[19] Preston TR and Leng RA. 1987. Matching ruminant production systtem with available resources in the tropics. Penambul Books. Armidale. ISBN: 0958829012

[20] Arora SP. 1989. Digestion of microbes in ruminants. Gadjah Mada University press. Yogyakarta. Indonesia (In Indonesian)

[21] Isroi. 2008. Compost. Indonesian Plantation Biotechnology Research Institute. Bogor. Indonesia (In Indonesian)

[22] Hanafi ND. 2008. Animal feed preservation technology. Faculty of Agriculture. Digital library. University of North Sumatera. Medan. Indonesia (In Indonesian)

[23] Crampton EW and Harris LE. 1969. Applied animal nutrition. 2nd Ed. W.H. Freeman and Company, San Fransisco.

[24] Church DC. 1988. The ruminant animal digestive physiology and nutrition. Prentice Hall, Englewood Cliffs. New Jersey. USA.

[25] Gallert C and J Winter. 1999. Bacterial metabolism in wastewater treatment systems. Environmental Processes I. Weinheim: WILEYVCH Verlag GmbH \& Co. KgaA.

[26] Sutardi T. 1979. The resistance of food proteins to degradation by rumen microbes and the benefits for increasing livestock productivity. Proceedings in Seminar Research and Supporting on Animal Husbandry Development. Animal Husbandry Research Center. Bogor. Indonesia. Book 2 pp: 91-103. (In Indonesian)

[27] Loosli JK and IW McDonald. 1968. Non protein nitrogen in the nutrition of ruminants. Food and Agriculture Organization of the United Nations, FAO Agriculture Studies, Italy. 73.

[28] Purbowati E, E Rianto, W S Dilaga, C M S Lestari and R Adiwinarti. 2014. Characteristics of rumen fluid, types, and number of microbes in the rumen of Javanese cattle and Ongole peranakan. Animal Husbandry Bulletin, 38: 21-26. Indonesia (In Indonesian)

[29] McDonald P, Edwards RA, Greenhalgh JFD and Morgan CA. 2002 Animal nutrition. Ed ke-6. Gosport (UK): Ashford Color Pr.

[30] Orskov ER. 1992. Protein nutrition in ruminants. 2nd Ed. Academic press, 24-28 oval Road, London. NWI 7DX. pp. 20-42.

[31] Astuti T. 2014. Evaluate the characteristics of palm oil waste fermented with local microorganisms of livestock waste as ruminant animal feed ingredients. Universitas Muara Bungo. Bengkulu. Indonesia (In Indonesian)

[32] Liu JX, Susenbeth S and Sudekum KH. 2002. In vitro gas production measurements to evaluate interactions between untreated and chemically treated rice straws, grass hay, and mulberry leaves. Journal of Animal Science, 80: 517-524. 